\title{
Research of College Students' Physical Training and Lifelong Physical
}

\section{Education}

\author{
Jie Zhang ${ }^{1}$ \\ ${ }^{1}$ YuLin University Sports Department,Shaanxi Province,YuLin,719000. \\ a email
}

KEYWORDS: College students; physical fitness; Lifetime Sports; Health

\begin{abstract}
Lifelong sports consciousness is a sportconcept advocated in today's knowledge-based economy and fully train and develop students' lifelong sports consciousnesswill be the inevitable trend of historical claims.The status of college students' physical of physical educationquality in this paper was discussed and based on it, this paper proposed the concept of lifelong physical education of college students thought and discussed the cultivation of students' lifelong sports consciousness.
\end{abstract}

\section{Introduction}

Lifelong sports is a person lifelong adhere to physical exercise and receive physical education. It is under the influence of modern formation of Lifelong Education, it is to improve the unity of the human physique engineering process in human life. Student access to higher education is a special stage, learned during the school sports technology, skills, new jobs in many of them do not have access, this College Students' Physical Education Reform proposed new ideas and direction. Therefore, how to lay the foundation for lifelong college sport and is the need to develop and market the next era of economic conditions. Today's social change and technological revolution has a higher body mass demand to people's leisure life more and more. Modern civilization on human health has brought some adverse effects. To accommodate high-speed, high-intensity, fast-paced work on the human body challenge students during the school should combine their interests, hobbies and physical characteristics, so that they learn the necessary sports basic theoretical knowledge, develop their awareness and ability to exercise.

On college campuses, sports curriculum is a physical exercise as the main means to enhance the health of college students as the main purpose of the required courses. Lifelong Sports Awareness Training is also an important aspect of college physical education, the core content is to require school sports should be based sports and entertainment, sports and fitness, sports and other traditional sports and family as the main teaching content, not only to master the scientific theory and engage in physical exercise The method of physical exercise, develop good exercise habits, and lifelong sports ideology for the realization of lifelong sports and lay a good foundation.

Lifelong Sport is a new concept since the 1990s reform and development of sports proposed. The implication is that a person should have lifelong physical exercise and receive physical education. Lifelong Sports Awareness Training is also an important aspect of college physical education. Students awareness of lifelong physical exercise, can help students master the method of self-training and improving the physical ability, the future of the students into the community, it has 
extremely important practical significance. School of Physical Education is the key to lifelong sports consciousness, not only to lay the foundation for students 'lifelong physical sports, more important is to develop awareness of students' lifelong sports, habits and abilities. On the one hand people from the beginning of life until the end of life to learn and participate in physical exercise, so that there is a clear purpose for life, so that life is always life sports become an important and indispensable content; the other is under the guidance of lifelong PE thought to System of sports, overall as the goal, and his practice offers opportunities to participate in sports activities at different times, in different areas of life.

\section{Status of Physical Education in Colleges and Universities}

In College Physical Education and teaching to implement lifelong physical education, we must first understand the current situation of Physical Education in Colleges and Universities. Physical education is a basic form of organization of college sports is the main way to achieve the purpose of college sports. College Physical Education should not only pay attention to physical exercise and its effect students in school, and more importantly, how to teach students to be lifelong physical exercise.

Current students professional knowledge, technology, skills, learning and mastering a strong practical purpose, motivation to participate in physical exercise is generally not high, relatively weak sense of fitness, exercise and do not know their own sense of lifelong fitness. Their basic activity and physical fitness and poor, basic knowledge of sports, technology and skills, learning enough, often under pressure of objective conditions, it had to do an activity to engage in.

Physical education teaching model currently used in our country, most of the teachers according to teaching plans and teaching consciousness, how teachers say the students how to do it. The whole process of physical education, teachers are instigators, organizers, mentors; students are learning under the guidance and supervision of trained teachers. This ability teaching model and college students, opinion, personality development are incompatible.

\section{Relationship between Lifelong Sports and University Athletics}

Colleges and universities are training personnel base, physical education is the basis for the training of personnel, qualified personnel in addition to a profound professional knowledge, but also must have a healthy body. Talent is the carrier of knowledge, and people need health as a material basis. Physical features can effectively improve and enhance the body's health. Bound to maintain a healthy long-term unremitting, regularly exercise. But lifelong sports behavior also need to develop exercise habits, understand the relevant knowledge and mastery of a certain body fitness method, which are an important part of college physical education and teaching. Visible, College Physical Education is one of the most important and most critical stage Lifelong Sports Habits.

Colleges and universities are students receive education and important position, and its impact on students' educational content deep. College Physical Education should seize the opportunity to strengthen the training of body awareness, reuse process of physical exercise, to improve its ability to independently exercise, strengthening lifelong sports concept, knowledge and grasp the correct way to exercise, so that universities become lifelong sports behavior of realization actual place. In the long process of lifelong sports, college sports especially sports teaching task is to check students' lifelong physical exercise and improve physical and mental qualities intelligent reserve. Visible, college physical education has an important significance in lifelong sports. 
Lifelong physical ideology is the new requirements of modern education for Physical Education. With the development of modern sports, lifetime sports ideology has increasingly shown its importance. Lifelong sports not only be able to train all-round development of moral, intellectual, physical talent, but also the entire Chinese nation to improve physical fitness and train a large number of excellent sports talents, has profound practical and historical significance for the development of modern sports.

School sport is the foundation for lifelong physical education. School systems in Lifelong Sports, plays a connecting role, is an important part of lifelong sports, sports people and laid the foundation for lifelong critical period.

A student, it is to lay the foundation of the body "golden age." From the development of the body's own point of view, this period has special significance. If during this period should be exercise and did not get to the future, the passage of time and then exercise, although there are effects, but not due to lay the foundation, is often less effective. We must look to the future, first of all from now on. Ensure energetically while studying lay the foundation for lifelong sports.

"Self-sports consciousness" from consciousness, self-consciousness derived. Understanding of lifelong sports, the key is to develop sports consciousness. Consciousness is the human mind reflect the objective material world, it is feeling the sum of the various psychological processes of thinking and so on. By extension sports consciousness, the human mind is a reflection of sports objective things, a variety of psychological processes in sport feeling, thinking, and so on. Here is "self-sports consciousness", is their treat sports in mind.

"Self-sports consciousness" is the core of lifelong physical exercise, only to establish self-sports consciousness, in order to achieve the goal of lifelong sports consciousness and actively participate in physical exercise. First, improve the physical training of rational understanding. Students are not only one-sided pursuit of immediate interest in sports, but should for sports purpose, meaning, role and function have a comprehensive understanding. Change from passive to active, to become the main sports learning and various sports activities.

Second, they shouldunderstand themselves and understand their own physical and mental and physical development of the specific situation. Athletic ability, motor skills level, in particular, to learn from the reality, learn from each other and carry out learning and exercise.

Third, self-sports consciousness is formed in repeated practice. Repeatedly uninterrupted practice, deep the emotional experience of sports, and constantly improve the level of sports, make physical exercise a conscious initiative behavior.

\section{Achieve the Combination of Physical Fitness Training and Lifelong Physical Education}

School is lifelong physical education the most advantageous place. Students into the community, can continue to regularly engage in physical exercise, depending on their most fundamental lifelong sports consciousness, and therefore should realize the organic combination of University Physical Education and Lifelong Physical Education of College Students in the full body training to carry on in practice.

Students interest in sport, hobbies, develop good exercise habits, is to train students lifelong sports consciousness is the key. With the development of quality education in colleges and universities, students 'cultural knowledge constantly enrich and accumulation, improving the quality of their own, they have to get rid of the image, intuitive way of thinking, strengthen teaching sports theory at this stage, to change the students' thinking, culture their self-awareness and interest sports habits can have a multiplier effect. 
Sports competitions are important practical form of sport, school sports is one way to achieve goals. Schools should plan to organize different projects and different forms of various competitions, to attract the majority of students attend. Schools by organizing sports and cultural festival, sports associations and other activities, using a variety of forms of propaganda widely publicized, so that students realize transition from action.

Modern society continues to put forward new requirements for education and higher standards, educational philosophy and new teaching theory is in comply with such a request came into being. Lifelong sports consciousness, to help students master the method of self-training and improving the physical ability, the future of the students into the community, has extremely important practical significance, therefore, the school physical education is the key to lifelong sports consciousness training, not only for the students lay the physical foundation of lifelong sports, more important is to develop awareness of students' lifelong sports, habits and abilities.

\section{Conclusion}

Lifelong sports concept is a gradual process, which requires students to establish a correct outlook sports, awareness of physical exercise, while schools to carry out a variety of activities to increase interest in college students of physical exercise, enhance learning student sports theory, to create a good the teaching environment and conditions, continue to promote the formation of the undergraduate lifelong physical concepts.

College sports is the last part for a student in school, but also the highest level of sports school, the turning point a student from the school to the community and the convergence point of learning and use. College sports are an important part of the sport for life, but also the foundation for lifelong sportsand lifelong sports is a continuation and development of university sports.Only recognize their relationship, can we complete the task given college sports and improve lifelong ability. College physical education should make full use of good environmental practice for lifelong sports schools offer, seize the opportunity to strengthen the cultivation of students' lifelong sports consciousness and thought, master the method of physical exercise and improve the ability to exercise independent body.

\section{REFERENCE}

[1] Judith E., Karen E, \&Bonnie L. Foundations for the Learning and Instruction of Sport and Games [J]. Journal of Teaching in Physical Education. 15, 399-417, 2006.

[2] Chase, M. A, Ewing, M.E,Lirgg, C. D.,\&George, T. R. The Effect of Equipment Modification on Children's Self-Efficacy and Volleyball Shooting Performance [J]. Research Quarterly for Exercise and Sport, 65 (2),159-167, 2004.

[3]Stephanic Stoll Dalton.Pedagogy Matters: Standers for Effective Teaching Pravtive.Center for Research on Education, Diversity\&Excelleace, 1998.

[4] Reid W.A,Curriculum as Institution and Practive:Essays in the DeliberativeTradition.N.J.L.Erlbamn Associates, 2009. 